\title{
'n Beginselgrondslag vir gesag, vryheid, orde en dissipline in die onderwysopset van die vroeg-21 ste eeu
}

\author{
J.L. van der Walt
}

Fakulteit Opvoedingswetenskappe

Potchefstroomse Universiteit vir $\mathrm{CHO}$

POTCHEFSTROOM

E-pos: jlvdwalt@intekom.co.za

\section{Abstract}

A principial ${ }^{1}$ foundation for authority, freedom, order and discipline in the educational context of the early 21 st century

This volume of Koers contains a number of articles dealing with various aspects of authority, freedom, order and discipline in the educational context. The discussion in this, the introductory article, is based on the question whether postmodern conditions have brought about any changes to our views and ideas about these phenomena, especially since these conditions seem to favour relativism and to be averse to generalising "grand narrative"-views. In the discussion of each of these phenomena, the ramifications of extremely static and rigorous as well as of extremely fluid and dynamic approaches are considered. It is concluded that although cognisance has indeed to be taken of the needs and demands of postmodern man (in the shape of learners, for instance), persons in authority in educational context should strive to apply principles based on a Biblically-based/reformational view of man, society, authority, freedom, responsibility, accountability, order and discipline.

1 Die vertaling van die woorde prinsipieel en prinsipiële in Engels is altyd problematies. Dit kan nie vertaal word met principled nie, aangesien die konnotasies verskil. Die woord word dus om hierdie spesiale rede regdeur hierdie nommer met die gemaakte Engelse woord principial vertaal, aangesien dit die konnotasie die beste oordra.

The translation of the Afrikaans words prinsipieel and prinsipiële into English has always been a problem. It cannot be translated as principled as the connotation would not be correct. The word is thus, for this specific reason and for purposes of this complete issue, translated as a newly-minted English word, viz. principial seeing that this word is the best carrier of the required connotation. 
Opsomming

'n Beginselgrondslag vir gesag, vryheid, orde en dissipline in die onderwysopset van die vroeg-21 ste eeu

Hierdie Koers-bundel bestaan uit 'n aantal artikels oor verskeie aspekte en fasette van gesag, vryheid, orde en dissipline. Die bespreking in hierdie inleidende artikel is gebaseer op die vraag of die heersende postmoderne kultureel-lewensbeskoulike omstandighede enige veranderinge meegebring het in die wyse waarop hierdie verskynsels benader (behoort te) word - in hierdie geval in onderwyskonteks - aangesien die postmoderne benadering 'n voorkeur toon vir 'n relativistiese aanslag en afwysend staan teenoor starre "groot verhaal"-sienings. Die implikasies van sowel 'n uiters statiese, rigoristiese en starre benadering sowel as van 'n uiters vloeiende en dinamiese benadering tot elkeen van hierdie verskynsels word ondersoek. Die gevolgtrekking word gemaak dat, hoewel daar inderdaad gereken moet word met die behoeftes en eise van die postmoderne mens (in die persoon van die leerder), gesagsdraers in onderwyskonteks steeds behoort te poog om beginsels gefundeer in ' $n$ Bybelse/reformatoriese siening van die mens, samelewing, gesag, vryheid, verantwoordelikheid, toerekenbaarheid, orde en dissipline tot toepassing te bring.

\section{Inleidende opmerkings en strategie}

In die reeks artikels wat hierna volg, handel die onderskeie skrywers oor ' $n$ verskeidenheid onderwerpe wat almal op die een of ander manier verband hou met die vraagstukke van gesag, vryheid, orde en dissipline in die onderwys- of skoolopset. Temas soos die volgende kom aan die orde: die herstel van dissipline in skole, skoolreëls en gedragskodes, 'n vergelykende perspektief op dissiplinehandhawing in die onderwys, die rol van waardes in die handhawing van dissipline, die voorkoms van dissiplinêre probleme in skole, leerderdissipline in openbare skole, alternatiewe vir liggaamstraf, die vraagstuk van dwelmmisbruik in skole, straf teenoor voorkomende maatreëls, 'n leerderperspektief op dissipline, en die rol wat orde (kan) speel in die voorsiening van doeltreffende onderrig en leer. Hoewel daar 'n onmiskenbare tematiese draad deur al hierdie bydraes loop, word dit nie sonder meer heeltemal duidelik op watter beginselgrondslag die vraagstuk van gesag, orde en dissipline in die onderwys- en skoolkonteks (behoort te) rus nie. 
Hierdie inleidende artikel is gefokus op die trek van die buitelyne van sodanige grondslag. ${ }^{2}$

Die volgende stappe word hierna uitgevoer in die besinnende soeke na 'n grondslag. In eerste instansie word aandag gegee aan enkele voorafvrae op die weg tot 'n gefundeerde antwoord op die vraag na 'n grondslag. Daarna word 'n voorlopige konklusie getrek met betrekking tot hoe sodanige gefundeerde antwoord daar kan uitsien. Dit word gevolg deur 'n kort fundering van die verskynsels gesag, vryheid, orde en dissipline vanuit Bybelse denkraamwerk en 'n finale konklusie word getrek.

\section{Enkele voorafvrae op die weg na 'n ewewigtige antwoord}

Voordat tot ' $n$ nadere bepaling van 'n moontlike beginselgrondslag vir hierdie reeks verbandhoudende temas gekom kan word, is dit nodig om aan enkele voorafvrae aandag te gee.

\subsection{Vereis 'n nuwe - postmoderne - tydsgewrig 'n nuwe benadering tot funderingsvrae?}

Die mens van die vroeg-21ste eeu bevind hom of haar in 'n "postmoderne" omgewing. Die term "postmodern" verwys hier, op voetspoor van Hargreaves (1994:38 e.v.), Moore (1996:136-7), Ward (1997:11 e.v.), Neutjens (2000:286-287) en andere, na 'n veranderde kultureel-lewensbeskoulike milieu of konteks. Die mens van hierdie tydsgewrig beskou homself as vry, outonoom (selfwetgewend), en is onwillig om die self te onderwerp aan die dwang of die dissipline van die een of ander oorkoepelende orde of "groot verhaal" (sogenaamde grand narrative of algemene denkraamwerk), veral as dit heteronoom ontwikkel en toegepas word. Dit val buite die bestek van hierdie besinning om 'n volledige oorsig te gee van die mensbeskouing verbandhoudend met die postmoderne kultuuren lewensbeskouing. Dit is desondanks nodig om te let op die feit dat die postmoderne kultureel-lewensbeskoulike opset dit bykans onmoontlik maak om die vraagstukke van gesag, vryheid, orde en dissipline in terme van vaste beskrywings, definisies of algemene raamwerke te giet of te benader, en boonop te verwag dat die hedendaagse mens sy postmoderne vryheid gaan inboet net om iewers in hierdie "groot verhaal" ingepas te word. Die hedendaagse, 
postmoderne mens weier om in sulke statiese vorms gegiet en dus "gevries" te word. Volgens Middleton en Walsh (1995:35) is die afwysing van "a total scheme of things because it is both unattainable and inherently violent" ' $n$ herhalende postmoderne tema.

As 'n mens dus soek na die beginselgrondslag van gesag, vryheid, orde en dissipline in 'n postmoderne tydsgewrig kan dit nie gedoen word soos wat enkele dekades gelede nog kon gebeur nie, naamlik om die verskynsels gesag, vryheid, orde en dissipline in relatief vaste (selfs rasionalistiese) definisies of skemas te giet, en dan deduktief te soek na toepassings vir hierdie definisies in die onderwys- of die skoolopset nie.

Om hierdie punt prakties te illustreer: Voorheen sou reformatoriese (insluitend opvoedkundige) denkers eksponente kon wees (vgl. De Klerk, Duvenage \& Van Wyk, 1973:292; Van der Walt \& Dekker, 1983:276 e.v.) van 'n relatief starre hiërargiese gesagsbeskouing, wat min of meer soos volg sou lyk: God is dié Gesaghebber, en die onderwyser (byvoorbeeld) ontvang gedelegeerde of afgeleide gesag van Hom (ongeveer soos die maan die lig van die son weerkaats), onder meer weens die onderwyser se geroepenheid tot die taak van onderwys-gee, andersyds weens sy opleiding en kompetensie as onderwyser, en ook weens sy of haar aanstelling deur die een of ander onderwysowerheid. Die onderwyser beskik ook oor gesag voortvloeiend uit die krag van sy of haar Godgegewe persoonlikheid. Die term "gesag" hou verder ten diepste verband met "sê": die ondergeskikte behoort hom of haar te laat "gesê" deur die oorgeskikte. Wie hom deur 'n gesaghebbende persoon laat "gesê", is gehoorsaam, en gehoorsaamheid lei tot orde. Wie hom deur 'n kompetente en gesaghebbende persoon laat "gesê", word meteen ook ' $n$ volgeling of dissipel van die gesaghebbende, soos die onderwyser. Dissipelskap of dissipline werk eweneens orde in die hand.

Verder: Omdat die skepping ordelik is en aan ordegewende wetmatighede onderworpe is, moet daar van die veronderstelling uitgegaan word dat ook die onderrig-leersituasie ordelik behoort te wees ten einde effektief of doeltreffend te kan wees. En hierdie orde kan slegs bewerkstellig word op grond van die teenwoordigheid van 'n onderriggewer wat tegelyk 'n ordeskepper is, onder meer deur gesaghebbend die ondergeskiktes (die leerders) te "gesê", en daardeur van hulle getroue volgelinge te maak. Die ondergeskiktes (die leerders) beleef hulleself as vry mense slegs binne die raamwerk van sodanige gesaghandhawing en -uitoefeningsproses. 
Dit is duidelik dat ' $n$ mens in die voorafgaande uiteensetting van die verband tussen gesag, vryheid, orde en dissipline met 'n veralgemenende "groot verhaal" - aldus die postmoderne benadering te make het: dit is 'n "verhaal" wat alle situasies kan omvat; al die elemente daarvan pas netjies in mekaar; die een element is die noodwendige resultaat van interaksie met ander elemente en weens die werking van ander elemente, en dies meer. Dit is ook duidelik dat ' $n$ mens inderdaad in gunstige omstandighede 'n ordelike en gedissiplineerde onderwys- of skoolopset sou kon bewerkstellig op grond van hierdie uiteensetting.

Die probleem waarvoor ' $\mathrm{n}$ mens met hierdie besinning aan die begin van die 21ste eeu staan, is dat die hedendaagse mens nie meer in sulke "groot verhale" of universeel-geldende raamwerke belangstel nie, en ook nie daar wil inpas nie. 'n Mens merk dit aan die feit dat die mens van hierdie eeu eerder vashou aan 'n versameling fundamentele menseregte en -vryhede, ${ }^{3}$ veral van toepassing op die enkeling asook op die enkeling as deel van 'n groep of gemeenskap. Hierdie versameling regte behoort vir die postmoderne mens verkieslik nie die vorm van 'n "groot verhaal" aan te neem nie. Hy wil nie in die dwangbuis of die drukgang van die een of ander dominerende of veralgemenende sisteem vasgevang wees nie. Daarom word gevind dat sulke regte en vryhede normaalweg slegs op 'n rytjie geplaas word (slegs netjies gelys) en dat hulle nooit in die een of ander omvattende beginsel- of grondslagraamwerk aangebied of verantwoord word nie (vgl. as voorbeeld hiervan hoofstuk 2 van die Grondwet van Suid-Afrika, wet 108 van 1996) (Republiek van SuidAfrika, 1996).

As gevolg van hierdie neiging vind ' $n$ mens dat twee verskynsels toenemend kop uitsteek: Aan die een kant die aandrang van die individu op, en die uitoefening van allerlei vryhede (van beweging, van assosiasie, van mening, van godsdiens, van seksuele oriëntering en vele meer - dikwels sonder dat dit uitdruklik ${ }^{4}$ gefundeer is in die een of ander fundamentele denkraamwerk). Aan die ander kant weer vind 'n mens 'n ineenstorting van "dissipline" gebou op die

3 Die gedagte dat die mens oor fundamentele regte en vryhede beskik en dat hierdie regte erken en eerbiedig moet word, is baie ouer as die postmodernisme. Die postmoderne mens vind egter besondere aanklank by die aandrang op die erkenning van hierdie menseregte.

$4 \quad$ Elke mens of groep se beskouing van vryheid is egter ten diepste gefundeer in die een of ander fundamentele raamwerk; die fundering is nie altyd eksplisiet nie. 
"groot gesag en orde-verhaal" van voorheen. Hoewel 'n mens moet waak teen simplistiese en ongenuanseerde gevolgtrekkings, kan die afleiding gewaag word dat 'n mens hier moontlik met ten minste een bydraende faktor te make het tot die feit dat dissipline- en ordeprobleme tans wêreldwyd kop uitsteek, onder meer in skole (vgl. Steyn, Wolhuter, Oosthuizen \& Van der Walt, 2003).

Die kern van die probleem lê egter veel dieper, naamlik ook in die uitgangspunte van die "ou" of tradisionele gesagsvisie waarmee daar dikwels in die verlede gewerk is (vgl. die "groot verhaal"uiteensetting pas hierbo), ook in die opvoedings- en onderwysopset (Van der Walt, 2003:150). Die tradisionele hiërargiese gesagsvisie kan onderdrukkend wees (en dus het die postmoderne mens 'n geldige punt beet in sy/haar verset daarteen). Die probleem met die tradisionele gesagsvisie is dat daar nie 'n prinsipiële onderskeid gemaak word tussen die absolute gesag van God en die relatiewe en feilbare gesag van die mens as geskape wese en gesagsdraer nie. Omdat hierdie onderskeid nie raakgesien word nie, word gemeen dat God sy gesag aan die mens "gedelegeer" of "oorgedra'" het, met ander woorde dat die gesag van die mens "afgeleide gesag" is, en dat die gesag van die mens 'n "afskaduwing" van die gesag van God is. Menslike gesag word in so 'n siening oorskat. Feilbare menslike gesag word vergoddelik, omdat die radikale onderskeid tussen God en die mens in so 'n hiërargiese werklikheidsvisie nie erken word nie (Van der Walt, 2003:156). Hierdie tradisionele hiërargiese gesagsbeskouing kan gevolglik onderdrukkend, outoritêr, tiranniek en totalitêr wees in die sin dat allerlei onregte deur gesagsdraers gepleeg kan word in die waan dat die gesag waarmee dit gedoen word, van God kom of "afgelei" is. In opvoedings- en onderwyskonteks merk 'n mens die uitwerking van so 'n gesagsbeskouing waar die ouer of die onderwyser absolute gehoorsaamheid van die opvoedeling eis, selfs wanneer die opvoeder heeltemal onbillik en onverantwoord optree.

Die postmoderne omstandighede waarin die hedendaagse mens leef, verg dus inderdaad 'n nuwe benadering tot funderingsvrae. Dit skakel egter nie die plig tot soeke na 'n Bybelsgefundeerde, reformatoriese beginselstandpunt uit nie.

\subsection{Beginseldenke versus waardedenke}

Die tweede voorafvraag op die weg van besinning oor die beginselgrondslag van verskynsels soos gesag, vryheid, orde en dissipline het te doen met die feit dat beginseldenke in die laat 20ste eeu al ongewild begin raak het. Beginseldenke roep assosiasies met 
"vastheid", "starheid", "onbuigsaamheid", en die "groot verhale" van die rasionalistiese verlede na vore. Beginsels is naamlik vertrekpunte, en dié is relatief vas en onbuigsaam, onder meer omdat hulle op die een of ander wyse in 'n mens se lewensopvatting ingebed lê. Dit val buite die bestek van hierdie besinning om 'n volledige uiteensetting van al die kenmerke van 'n lewensopvatting te behandel (vgl. daarvoor Van der Walt, 1999:47 e.v.). Dit is belangrik om raak te sien dat die lewensopvatting wat 'n persoon huldig, vir hom of haar soos 'n betroubare kompas of padkaart dien, en dus nie sonder grondige redes verander (kan word) nie. (Dit verander wel onder bepaalde omstandighede, 'n verskynsel waarop nie nou ingegaan kan word nie.5) Beginsels is ' $n$ faset van hierdie relatief vaste en betroubare padkaart, en kan onder bepaalde omstandighede as star en relatief onveranderlik van aard beskou word.

Vir die postmoderne mens, wat 'n hoë premie plaas op allerlei eie, individuele en groepsvryhede en menseregte, is dit ongemaklik om onder die dwang van beginsels geplaas te word. Beginsels vorm naamlik die grondslag vir norme of behorenseise, en baie van hulle is ook groeps- of gemeenskapsgebonde: Indien 'n mens van 'n sekere beginsel uitgaan, dan volg dit dat jy sus of so behoort op te tree. Beginsels, veral heteronoom-geformuleerde en -gesanksioneerde beginsels, met die gepaardgaande norme, word derhalwe deur die mens van die vroeg-21ste eeu as 'n dwangbuis of drukgang beskou. Dit bots teen die tipiese "ek-perspektief" (subjektivisme) van die "postmoderne mensbeskouing". 6 Die vraag na 'n beginselgrondslag vir gesag, vryheid, orde en dissipline in hierdie tydsgewrig is dus eintlik in 'n sekere sin vir die postmoderne mens 'n nonstarter, dit maak eintlik in die huidige postmoderne kultureellewensbeskoulike opset weinig sin. Dit sal dus - volgens die hedendaagse postmoderne mens - anders geformuleer moet word, en die vraag is: Hoe dan? Die antwoord sal waarskynlik wees: Formuleer dit in terme van waardes - vir die betrokke persoon in die betrokke kontingente situasie of omstandighede.

In teenstelling met 'n "modernistiese" (rasionalistiese) benadering, ingevolge waarvan onderwys gerig en bepaal word deur relatief vaste en onveranderlike beginsels, norme en denkpatrone (vgl. Middleton \& Walsh, 1995:18 e.v.), is daar tans 'n voorkeur vir

5 lemand wat hom tot die Christelike geloof bekeer, ondergaan so 'n verandering. Die apostel Paulus se Damaskus-ervaring is 'n voorbeeld hiervan. 
"waardes" eerder as vir "norme" of "beginsels". Die klem word geplaas op dit wat vir die betrokke individu, gegewe die situasie op daardie oomblik, van waarde is.

Waardes kan wissel na gelang van die situasie, is altyd relatief tot die situasie en die heersende omstandighede. Hulle is ook in hoë mate gebonde aan dit wat die betrokke individu in die gegewe situasie as waardevol beskou. Waardes is gerelativeer aan die individu, en nie noodwendig "vas" gewortel in die een of ander lewensbeskouing of religieuse standpunt of beskouing nie. Tennekes (1992:53) vat die gedagtegang agter die hedendaagse huldiging van waardes soos volg saam:

Waarden - dat wil zeggen concepties omtrent de waarde en de zin van het menselijk bestaan en de dinge waar het in het leven om gaat - vormen de basis zowel van het samenleven als van het beleid van een overheid die een verzorgingsstaat bestuurt. (Er) bestaat ... een geweldig waarden-relativisme. Waardeoordelen zijn verdacht, want subjectief en persoonlijk zo meent men. Waar het om gaat zijn de objectieve feiten en verder moeten mensen zelf maar weten welke waarden ze willen aanhangen. Het wordt ons voorgehouden dat we gedragscodes van de meest diverse aard hebben te respecteren of althans te tolereren. Waarden zijn ... een zaak van individuele voorkeuren, waarover mensen nu eenmaal met elkaar van mening verschillen.

Met die nadruk op waardes vervlugtig die basis waarop byvoorbeeld opvoedings- en onderwysbemoeienis gebou word, naamlik 'n vorm van konsensus oor wat ten minste as sentrale waardes beskou behoort te word (Tennekes,1992:55). Dié siening strook met Humalda (1995:73) s'n. Laasgenoemde wys daarop dat die huidige postmoderne tyd erkenning gee aan die feit dat mense verskillend is, en dat dit onmoontlik is om alle mense "op één noemer te krijgen".

In 'n reformatoriese denkraamwerk is daar egter plek vir sowel beginsels as waardes, maar prinsipieel anders gekonseptualiseer as in sowel die modernisme as die postmoderne denke. Beginsels is letterlik "begin-sels", dit wil sê (feilbare) positiveringe deur die mens, in 'n bepaalde tydsgewrig, plek, samelewingsituasie en omstandighede, van die wil van God wat $\mathrm{Hy}$ in die skepping en in sy Skrifgeworde Woord (die Bybel) weggelê het om ontdek te word (onder meer deur kultuurskeppende arbeid soos navorsing). Hierdie positiverings is formulerings of antwoorde van die mens in bepaalde omstandighede en neem die vorm van vertrekpunte of uitgangspunte en norme aan (maatstawwe aan die hand waarvan gedrag gemeet kan word). Die uitlewing van beginsels en die gehoorsaming 
van norme lei tot die verwesenliking van waardes. Sulke waardes hou verband met die situasie 7 waarin hulle gerealiseer word, maar veral ook met die samelewingsverband waarbinne die waarde tot uitdrukking kom.

Juis omdat hierdie formulerings (positiverings) antwoorde of response van die mens in bepaalde kontingente omstandighede is, is absolutisme (soos in die modernistiese denke) uitgesluit. Maar, aan die ander kant, omdat hierdie formulerings die menslike verstaan, formulering en toepassing van die konstante wil van God is, is totale relativisme (soos in die postmodernistiese denke) ook uitgesluit. Die feit dat die wette van God in en vir die skepping konstant is (God bly getrou aan sy woord; Hy onderhou die skepping getrou) beteken nie dat hulle staties in hulle werking is nie. Hulle bly dinamies (kragtig, soos 'n dinamo/kragopwekker) werksaam in die skepping, en dus ook in die skool as samelewingsverband en in die opvoedingshandeling.

\section{3 'n Bybelsgefundeerde denkraamwerk}

Die derde voorafvraag het te doen met die denkraamwerk van waaruit hierdie besinning plaasvind. In die soeke na 'n beginselgrondslag is dit belangrik dat ' $n$ mens - te midde van die vloeibaarheid van die postmoderne kulturele en lewensbeskoulike samelewingsopset waarin die mensdom tans staan - sal verduidelik vanuit watter denkraamwerk daar na die grondslag gesoek word. ("Denkraamwerk" is ook in die postmoderne opset bekend as die stem- of posisie-epistemologiese perspektief van waaruit 'n mens praat - O'Loughlin (1999)).

In hierdie geval word daarna gesoek vanuit 'n Bybelsgefundeerde denkraamwerk. Maar wat word met sodanige raamwerk bedoel? 'n Skerpsinnige antwoord op hierdie vraag vind 'n mens by Middleton en Walsh (1995) as hulle aanvoer dat enige denkraamwerk in wese gereduseer kan word tot vier kernvrae: (1) Waar bevind ons ons? (2) Wie is ons? (3) Wat het verkeerd geloop met die situasie waarin ons ons bevind en (4) Hoe kan hierdie situasie weer reggestel word? Die

$7 \quad$ In die onderwysopset kan die verwesenliking van waardes met die volgende voorbeeld verduidelik word. ' $n$ Leerder wat sekere antwoorde in 'n toets nie ken nie, skryf by sy maat langs hom af. Die waarde wat hier verwesenlik word is dat hy wel die toets slaag, maar ook weet dat hy oneerlik was. 'n Ander leerder besluit om nie af te skryf nie en verwesenlik 'n ander waarde deur sy optrede: hy slaag nie die toets nie, maar het die tevredenheid dat hy eerlik gebly het en nie aan die versoeking toegegee het nie. 
Bybelse antwoorde op hierdie vrae gee die buitelyne van 'n Bybelsgefundeerde denkraamwerk: (1) Ons is deel van 'n Godgeskape werklikheid, 'n werklikheid gekenmerk deur Goddelike wilsonderhorigheid, naamlik onderdanigheid aan Goddelike wetmatighede. (2) Ons is die kroon van die skepping, die beeld van God, rentmeesters in God se diens wat die skepping namens Hom moet bewoon, bewerk en bewaak. (3) Deur die sondeval het alles skeefgeloop, van God afvallig geraak. (4) Deur die herskeppings- en versoeningswerk van Jesus Christus is alles in beginsel herstel, en word dit deur die Heilige Gees toenemend aan Hom toegewy (geheilig) (Fernhout, 1997:84 e.v.).

Hierdie vier antwoorde vorm in wese 'n beginsel- of denkraamwerk van waaruit 'n mens die vraagstuk van gesag, vryheid, orde en dissipline kan benader. 8 Vanuit hierdie raamwerk moet dus van die postmoderne mens verskil word as hy die geldigheid van beginsels bevraagteken, en eerder kontingente waardes probeer aanhang. Die vermelde vier antwoorde op die lewensbeskoulike vrae vorm inderdaad 'n soort grondmotief of beginselraamwerk vir die soeke na 'n grondslag of fundering vir die verskynsels in die titel hierbo vermeld. Kennis behoort egter geneem te word van die feit dat in die huidige samelewingsopset (multikultureel, godsdienstig pluriform, postmodern, (de)konstruksionisties en vele meer) die reformatoriese stem dalk 'n eensame stem sal wees as hy probeer volhard met relatief vaste beginseldenke. In elk geval moet daarteen gewaak word dat die reformatoriese denkraamwerk 'n soort "groot verhaal"dwangbuis vorm. Een manier waarop dit voorkom kan word, is deur byvoorbeeld die onderdrukkende aard van 'n hiërargiese gesagsbeskouing te laat vaar. Die individuele verantwoordelikheid en toerekenbaarheid van die enkeling teenoor God en medemens moet daarteenoor erken en in ere herstel word.

\section{Soeke na ewewig}

Noudat hierdie voorafvrae aandag gekry het, kan die volgende voorlopige konklusie getrek word: In die soeke na 'n beginselgrondslag moet twee uiterstes, naamlik aan die een kant die relatiewe starheid van 'n "groot verhaal"-, algemeen-geldende of veralgemenende benadering, en aan die ander kant die vloeibaarheid en dreigende relativisme van 'n blatante (anything goes-soort, subjektivistiese) postmoderne benadering vermy word. Daar moet na ' $n$ alternatief

8 Telkens wanneer in hierdie uiteensetting gepoog word om 'n prinsipiële standpunt in te neem, kom hierdie denkraamwerk implisiet in werking. 
gesoek word, naamlik na 'n Bybels-gefundeerde reformatoriese visie. Die soeke na hierdie alternatief is op sekere aannames gebaseer:

- 'n Verantwoorde epistemologie (kenteorie) reken met die ontologiese uitgangspunt dat daar 'n objektiewe werklikheid buite die kenner (die subjek) is. Hoewel naïewe realisme verwerp word, is dit belangrik dat in ag geneem word dat daar 'n werklikheid is waarin die mens leef, moet skoolhou en onderwys gee - en dat hierdie werklikheid sekere vaste en konstante (universele) kenmerke vertoon. Die belangrikste kenmerk daarvan is dat God dit ordelik gemaak het; dit is onderworpe aan God se wil, met ander woorde daar is Goddelike wetmatigheid in die skepping te bespeur. Op grond hiervan kan dus gekonstateer word dat ook verskynsels soos skole en onderwys aan sekere vaste wetmatighede onderworpe (onderdanig) is, waardeur verseker word dat byvoorbeeld onderwys onderwys sal bly en nie tot iets anders sal degenereer nie. Daar ís dus vastighede in die skepping en in die onderwyswerklikheid waarmee gereken moet word. Gesaghandhawing, vryheidsuitoefening en -belewing, ordelikheid en dissipline het met ander woorde 'n onontkenbare en onontwykbare relatiewe vaste en onveranderlike (universele) kant, en dit moet erken word.

- Maar daarteenoor, en daarop het die postmodernisme die aandag opnuut gevestig, het die skepping ook 'n dinamiese kant. Niks in die skepping is finaal in beton gegiet nie; God het die mens in die skepping geplaas om dit verder tot ontplooiing (deur kultuurvorming) te bring. ' $\mathrm{n}$ Mens sou hierdie insig ook anders kon stel: binne die relatief vaste universele strukture wat onder God se wil en deur die hand van die mens tot stand gekom het, is daar ook die vloeiendheid en relatiewe veranderlikheid of partikulariteit wat verband hou met die kontingensie van die bepaalde oomblik en situasie. Daar is dus altyd 'n spanning tussen die universele en die partikuliere (of kontingente). Prakties gesproke: hoewel 'n onderrig-leersituasie altyd vaste of universele kenmerke sal vertoon waaraan ' $n$ mens dit kan herken as 'n onderrigleersituasie, vertoon dit ook partikuliere eienskappe: hierdie onderwyser (fasiliteerder) met hierdie groepie leerders (leerlinge) met hierdie bepaalde stel onderrigdoelwitte (-uitkomste) en hierdie bepaalde didaktiese aanpak (onderrig-leerstrategie). Dieselfde geld vir verskynsels soos gesag, vryheid, orde en dissipline (vgl. ook Padgett, 1996:131; Van der Walt, 2002:71 e.v.). 
Dit wil voorkom of die modernistiese (rasionalistiese, veralgemenende "groot verhaal")-benadering die nadruk te veel op die eersgenoemde eienskappe van die werklikheid geplaas het, terwyl die postmoderne benadering ("die klein ek-verhaaltjies van mense as individue") die nadruk hoofsaaklik op laasgenoemde vloeibaarheid en partikulariteit geplaas het. In die volgende afdeling word die buitelyne getrek van 'n Bybelsgefundeerde/ reformatoriese benadering tot gesag, vryheid, dissipline en orde. In die proses word gepoog om die voetangels van sowel 'n modernistiese as 'n postmodernistiese uiterste te vermy.

\section{Fundering van gesag, vryheid, orde en dissipline}

\section{1 Gesag}

Gesag het sy oorsprong ten diepste in God. Hy is die absolute Gesaghebber. Die mens, die beeld van God en die kroon van die skepping, is deur Hom geskep en geroep om die skepping te bewoon, te bewaak en te bewerk. Die mens is met ander woorde geroepe om die stadhouer of rentmeester van God in die skepping te wees, en vir die uitvoering van hierdie taak (respons op die roeping) benodig hy gesag. Die mens wat hom of haar op die een of ander manier in 'n oorgeskikte posisie bevind, beskik oor (feilbare, nie-absolute, menslike) gesag. 'n Onderwyser is so 'n oorgeskikte: hy of sy moet gesagvol en gesaghebbend optree teenoor diegene wat aan hom of haar ondergeskik is. Die onderwyser as gesaghebber verwerf sy of haar gesag uit hoofde van sy of haar geroepenheid tot die amp en taak van onderwysgewer, asook uit sy of haar opleiding, bevoegdheid en uiteindelike aanstelling as onderwyser deur 'n behoorlik gemagtigde owerheid.

Waar God se gesag absoluut is (geen duimbreedte van die skepping is nie aan Hom onderdanig nie), kan dieselfde nie van die gesag van die mens as gesagsdraer gesê word nie. Die mens se gesag is in drieërlei sin gerelativeer: eerstens is dit bloot feilbare menslike gesag, gekwalifiseer deur die bepaalde samelewingsverband 9 waarin dit uitgeoefen word en beperk deur die norm-

9 Daar bestaan nie soiets soos "gesag in die algemeen" of "generiese gesag" nie. Gesag is altyd konteksgebonde, derhalwe bestaan daar baie "soorte" gesag. Gesag en gesagsuitoefening word altyd gestempel deur die samelewingsverband waarbinne dit uitgeoefen word. Gesag is dus altyd "gespesifiseerd"'. In die geval van 'n onderwyser word sy of haar gesag gespesifiseer of gekwalifiseer deur die konteks en die normstruktuur van die skool as samelewingsverband. 
struktuur wat in die betrokke samelewingsverband geld; tweedens word dit medebepaal deur die situasie waarin die gesag uitgeoefen word, en derdens, word dit "gekontra-balanseer" deur die gesagsdraer se verantwoordelikheid en toerekenbaarheid aan God en medemens.

Die situasie (samelewingsverband) bepaal hoe die gesaghebber sy of haar gesag uitoefen. So, byvoorbeeld, is 'n onderwyser in die klaskamer die gesagdraer ten aansien van die leerders aangesien hy of sy die stigter en die bestuurder van die onderrig-leersituasie is. Die skool as samelewingsverband word gekwalifiseer deur onderrig en leer, dit wil sê logies-analitiese handelinge. Leerders word onderrig om helder en onderskeidend te dink, en om logies en akkuraat met gegewens, teorieë en modelle om te gaan (vgl. Van der Walt, 2003:165). Drie dekades gelede het Taljaard (1976:244) al die bestemming van die skool as "intellektuele ontwikkeling of ontsluiting" bestempel. Daarom is die gesag van onderwysers ook logies-analities gestempel of gekwalifiseer; alles wat 'n onderwyser doen in die konteks van die skool as lewensverband is gerig op die bevordering van die logies-analitiese (die onderrig-leer-) funksie of bestemming van die skool.

Die skool het egter ook (sekondêr) 'n opvoedingsfunksie: 'n funksie om jongmense toe te rus en voor te berei vir die lewe na die skooljare. Volgens Stone (1981:29) is die skool 'n "onderriginstituut of -struktuur wat deur opvoeding verder gekwalifiseer word". Daarom is die gesag van die onderwyser ook deur opvoeding gekwalifiseer: die bemoeienis van die onderwyser met die leerder het ten doel om laasgenoemde toe te rus en voor te berei vir 'n selfstandige en verantwoordelike volwasse lewe. Die onderwyser se opvoedingsgesag verskil egter van dié van die ouer. Anders as die ouer, wie se gesag deur ouerhuislike liefde gestempel is, is die gesag van die onderwyser logies-analities-toerustend gestempel. Die gesagsuitoefening van die onderwyser is met ander woorde ten diepste gerig op die bevordering van die onderrig-leertaak van die skool. In die loop van die uitvoering van hierdie funksie kom ook die opvoedingsfunksie van die skool aan die orde, maar sekondêr tot die basiese of primêre funksie van onderrig-leer van die skool.

Volgens Van der Walt (2003:159) beteken gesag ook om oor wysheid te beskik. En wysheid bestaan uit twee aspekte: insig in die aard en doel van die lewensverband waarin leiding gegee moet word, en gewilligheid om die norm te gehoorsaam en die doel na te streef. Indien 'n onderwyser nie hierdie insig in die struktuur en funksie van die skool asook in die struktuur en funksie van 
opvoedende onderwys toon nie, beskik hy of sy oor blote formele gesag (op grond van opleiding of 'n aanstelling deur die onderwysdepartement) maar nie oor werklike gesag, gesag wat gehoorsaamheid by leerders sal "afdwing" nie. Werklike gesag dui op gewilligheid tot voortdurende gehoorsaamheid: om God se wil vir die skool as spesifieke samelewingsverband al beter vir steeds verder ontplooiende (dinamiese, veranderende) omstandighede te positiveer (konkreet tot uitdrukking te bring).

Die gesagsdraer se gesaghebbendheid word verder in ewewig gehou deur verantwoordelikheid en toerekenbaarheid: menslike gesag is nie absoluut nie; in die geval van die mens is daar altyd iemand of die een of ander instansie waaraan 'n gesagsdraer vir sy of haar besluite verantwoordelik is. Die gesagsdraer is nie slegs verantwoordelik (responsible) teenoor die een of ander oorgeskikte persoon of instansie nie, maar ook toerekenbaar (accountable). Volgens Bybelsgefundeerde beskouing is die gesagsdraer in finale instansie verantwoording aan God verskuldig. 'n Gesagdraer is slegs 'n rentmeester en nie die baas of die eienaar van die betrokke samelewingskring (soos die skool nie). Hy of sy is slegs 'n trustee of 'n gemagtigde, en dra gevolglik groot verantwoordelikheid. Gesagsuitoefening veronderstel 'n noue band tussen vertroue en verantwoordelikheid en toerekenbaarheid (Van der Walt, 2003:166). Gesagsuitoefening is dus ook 'n vorm van respons op die mens se roeping deur God.

Die voorafgaande bondige besinning oor gesag toon dat gesag, wat die mens betref, nooit absoluut (staties, vas, "in beton gegiet") is nie, maar kontingent is wat die situasie betref, en verder deur verantwoordelikheid en toerekenbaarheid gekwalifiseer word. In laasgenoemde sin is die uitoefening van gesag vloeiend en dinamies. Hierdie siening moet steeds in die agterkop gehou word as daar byvoorbeeld in sommige van die hieropvolgende artikels sprake is van die herstel van dissipline in skole of wanneer daar sprake is van die "herstel van orde met die oog op die verskaffing van effektiewe onderrig en leer".

\subsection{Vryheid}

Vryheid is, soos verantwoordelikheid en toerekenbaarheid, 'n teenhanger en uitvloeisel van gesaguitoefening. Gesagsuitoefening, soos dit hierbo in 4.1 beskryf is, omskryf die parameters vir aanvaarbare gedrag. Die vryheid wat mense in 'n samelewing geniet, hou regstreeks verband met hoe die gesaghebbers hulle gesag en mag (die vermoë om gesag uit te oefen) toepas. Mag kan 
vryheid bevorder of vernietig (Van der Walt, 2003:162). 'n Gesagsdraer wat sy of haar gesag op verantwoordelike en toerekenbare wyse uitoefen, maak dit vir die gesagonderhorige duidelik wat die grense van aanvaarbare gedrag is. Hierdie stelling kan verduidelik word aan die hand van die volgende voorbeeld. In 'n fascistiese, outokratiese of tirannieke opset, waar gesagsuitoefening as 'n absolute reg van die gesagdraer beskou word (op grond van byvoorbeeld politieke of gewaande "oorerflike mag"), en hy of sy nie aan die een of ander oorgeskikte instansie verantwoording of toerekenbaarheid verskuldig is nie, word die vryheid van ondergeskiktes ingeperk - in die sin dat hulle voortdurend geknel word deur onbillike en wispelturige reëls en maatreëls. Omgekeerd: indien gesaguitoefening na die ander kant oorhel (laissez faire-benadering), dan verstaan die ondergeskiktes nie presies waar die grense vir aanvaarbare gedrag lê nie en hulle raak eweneens uitgelewer aan die grille, giere en wispelturigheid van die gesagdraers in kontingente situasies.

Vryheid in 'n demokratiese opset (in konstitusionele sin, maar ook in die onderrig-leersituasie) is dus in beginsel 'n fundamentele menslike reg, maar dit kan benadeel word deur die onverantwoordelike uitoefening van hulle gesag (mag) deur die oorgeskiktes. 'n Kultuur van "fundamentele menseregte en -vryhede" kan egter nie verdedig of regverdig word vanuit 'n blote mensgerigte of -gesentreerde funderingspunt nie. Die mens is naamlik geskep om te respondeer op sy Goddelike roeping tot kultuurbeoefening en rentmeesterskap. Slegs deur gepas te respondeer (in die vorms van gesagshandhawing of -uitoefening, en van gesagsonderworpenheid of -gehoorsaamheid) kan die mens waarlik vry wees voor die aangesig van God. Sulke response is nooit konteksvry nie; hulle vind altyd plaas in gegewe situasies, onder meer waarin gesag uitgeoefen en gehoorsaam word, en laasgenoemde situasies word altyd gekwalifiseer deur verantwoordelikheid en toerekenbaarheid. Slegs as hierdie response (sowel gesagsuitoefening as gesagsonderhorigheid) getuig van verantwoordelikheid lei hulle waarlik tot vryheid.

Hier is dus ook, soos in die geval van gesag, sprake van 'n relatief vaste kant sowel as van 'n relatief vloeiende kant: vryheid is nóg absoluut nóg totaal vloeiend en dinamies (libertyns).

Prinsipieel beskou is vryheid voorts nie bloot 'n uitvloeisel van gehoorsaamheid aan gesag nie. Die mens is oorspronklik geskep om God in vryheid te dien, maar het weens ongehoorsaamheid aan God 'n slaaf van die sonde geword. Deur die verlossingswerk van 
Jesus Christus is die vryheid van die (gelowige) mens egter weer in beginsel herstel. Die gelowige is nie net vrygemaak van die sonde nie, maar ook vrygemaak om God met oorgawe te dien. Weens die gebrokenheid van die huidige bedeling is die mens egter nog geneig om steeds aan God ongehoorsaam te wees, en steeds in die strikke van die sonde te trap. Om hierdie rede staan die gelowige onder die deurlopende roeping om te stry vir vryheid deur meer gehoorsaam aan God en sy verordeninge te wees as aan enige menslike gesag of verordeninge.

Indien daar dus in een (of meer) van die hieropvolgende artikels sprake is van skoolreëls, van 'n gedragskode, van dissiplinêre probleme, van straf vir verkeerde gedrag en dies meer dan moet hierdie fundering as agtergrond daarvan verstaan word: die gedrag van leerders kan slegs as "vry" en "verantwoordelik" gesien word indien hulle gesaghebbers op verantwoordelike en toerekenbare wyse grense vir hulle gedrag gestel het. Straf vir "verkeerde" gedrag is byvoorbeeld nie regverdigbaar indien dit nie vir die "oortreder" duidelik is wat die aanvaarbare grense vir gedrag is nie. En sulke grense kan slegs gestel word deur verantwoordelike en toerekenbare gesagsdraers. Gesagsdraers moet ook nie struikelblokke in die weg van gesagsonderhoriges plaas nie; hulle moet met ander woorde nie die gesagsonderhorige voor die keuse plaas om meer aan hulle as aan God gehoorsaam te wees nie. Hierdie beginsel geld ook in die skool as samelewingsverband. Die gesagsuitoefening van onderwysers behoort in beginsel nie die vryheid van die leerders in die gedrang te bring nie, onder meer deur van die leerders iets te verwag wat hulle kan noop om meer gehoorsaam te wees aan mense as aan God nie.

\subsection{Orde}

Wat orde betref, moet deurgestuur word tussen absolute starheid en totale vloeibaarheid. Orde as absolute starheid is te bespeur in byvoorbeeld 'n militêre opset, waar dit op funksionele gronde geregverdig kan word. "Orde" as totale vloeibaarheid is daarteenoor te sien in situasies gekenmerk deur chaos, of deur "georganiseerde chaos": 'n vorm van wanorde wat desondanks lei tot die gewenste uitkomste. Laasgenoemde kan 'n mens vind in klaskamersituasies waar die oënskynlike wanorde deur die onderwyser of die fasiliteerder op so 'n manier bestuur word dat die gewenste resultate of onderwysuitkomste wel op 'n manier bereik word. Volslae vloei- 
baarheid is uiteraard ook merkbaar in totale wanordelike situasies (anargie, betogings wat skeefloop en dies meer). ${ }^{\mathbf{1 0}}$

'n Meer aanvaarbare vorm van orde kom tot stand indien 'n mens tussen hierdie twee uiterstes deurstuur en na die Bybelse beginsel soek, ook wat die onderwysopset betref. In 'n opvoedende onderwyssituasie wil 'n mens nie graag ' $n$ vorm van militêre orde afdwing nie, maar aan die ander kant ook nie die klaskamersituasie (byvoorbeeld) in volslae chaos laat ineenstort nie. Hoe kan hierdie gewenste vorm van orde bewerkstellig word? Vir 'n antwoord op hierdie vraag moet teruggegryp word na verantwoordelike en toerekenbare gesagshandhawing, waaruit regverdigbare vryheid (grense vir gedrag) spruit. Indien gesagshandhawing op verantwoordelike wyse geskied, en die leerders (byvoorbeeld) die grense van die vryheid vir hulle gedrag daarin ontdek en verstaan, dan volg 'n vorm van onderwys-funksionele orde. 'n Mens kan kwalik aan orde dink in die afwesigheid van verantwoordelike gesagshandhawing, die daaruitspruitende ontdekking van die grense van gedrag (vgl. die rol wat 'n gedragskode hierin kan speel), en die vrywillige aanvaarding van ordelikheid wat op sy beurt uit hierdie ontdekking van grense spruit. Orde is met ander woorde die gevolg van die mens (in hierdie geval sowel onderwyser as leerder) se antwoord (geformuleer in die vorm van beginsels en norme) op God se wil vir die betrokke samelewingsverband, in hierdie geval die skool. Die orde in die skool is eiesoortig, uniek aan die skool as lewensverband: dit is 'n vorm van ordelikheid wat die onderrig-leerhandeling bevorder, 'n vorm van orde wat die skool as lewensverband in staat stel om sy bestemming, roeping of funksie optimaal te kan uitvoer. Orde is dus in 'n sekere sin die gevolg of die resultaat van die insig wat die lede van die skool in die doel en funksie van die skool as lewensverband openbaar. Dit is die toestand wat in die skool (die klaskamer) heers waarmee die skool (insluitende die onderrig-leerhandeling) bevorder kan word. Wanorde heers wanneer daar ' $n$ toestand in die skool heers waarbinne dit onmoontlik is om die doel en bestemming van die skool te verwesenlik.

Dit val buite die bestek van hierdie besinning om volledig in te gaan op die kwessie van orde in die skepping, en dus op orde as 'n

10 Die demokratiese of egalitêre visie van amp en gesag veronderstel dat gesag van onder (van die "mense") na bo (na die gesaghebbers) oorgedra word. Waar 'n "van bo na onder gesagsbeskouing" die deur tot magsmisbruik oopmaak, hou hierdie beskouing die gevaar in dat ampte nie eerbiedig word nie, wat anargisme tot gevolg kan hê (Van der Walt, 2003:157). 
gevolg van die wetsonderhorigheid van die geskapene (vgl. egter Fowler, 1991:21 e.v.). Daarom moet volstaan word met die opmerking dat, soos alle ander dinge in die skepping, die opvoedende onderwyssituasie ook 'n inherente (Godgegewe en -geskape) orde het. 'n Mens kan byvoorbeeld die opvoedende onderwyssituasie soos dit universeel voorkom, beskryf aan die hand van die konstante universele orde-eienskappe wat dit vertoon. Dieselfde geld vir die mens as geskapene: daar sit ook 'n bepaalde orde in menswees. En dit geld ook vir byvoorbeeld die leerhandeling. Die orde-likheid van menswees kom egter tot konkrete uitdrukking in die kontingensie van partikuliere situasies en menslike gedrag.

'n Mens kan op grond van die voorafgaande redenasielyn tot die volgende gevolgtrekking kom: Die inherente orde in menswees, in die leerhandeling en in die opvoedende onderwyssituasie behoort deur die gesagdraer gefokus te word op die benutting daarvan vir die doeleindes van doeltreffende onderrig en leer in die onderrigleersituasie.

As daar dus in een of meer van die hieropvolgende artikels van "orde" in die onderwys- of skoolopset sprake is, dan is dit ten diepste gefundeer in hierdie siening van orde. Die "herstel van dissipline", "dissiplinêre sanksies", 'n gedragskode, die aard van dissiplinêre probleme, leerderdissipline, die uitskakeling van dwelmmisbruik in skole, en orde as voorwaarde vir doeltreffende onderwys is alles gefundeer in hierdie siening van orde: orde as resultaat van enersyds verantwoordelike gesagshandhawing, maar andersyds ook as 'n toestand wat die skool in staat stel om sy funksie en roeping as samelewingsverband te vervul.

\subsection{Dissipline}

Ook wat dissipline betref, moet daar deurgestuur word tussen 'n statiese en totaal vloeiend-dinamiese beskouing. Die term "dissipline", soos hierna verduidelik in die artikel getitel "A classical approach to the restoration of discipline in South African schools", is afgelei van "dissipel" wat "volgeling" beteken (Fernhout, 1997:88). 'n Statiese benadering tot dissipline (dissipel-vorming) kan lei tot starheid. Voorbeelde hiervan is indoktrinasie (om die leerder op so 'n wyse te beïnvloed dat dié nie 'n keuse het om die beïnvloeding vrywillig te aanvaar of te verwerp nie), demagogiese beïnvloeding (eenrigting-meningsvorming deur 'n persoon met kragtige invloed), of drakoniese vorme van straf (soos liggaamstraf, of straf gefundeer in die motief van vergelding vir oortreding: vergelyk die artikel getitel "Preventive or punitive disciplinary measures in South African 
schools: which should be favoured?"). Ook outokratiese, fascistiese en alle ander totalitêre benaderings val in hierdie kategorie.

Omgekeerd kan 'n totaal vloeiende, dinamiese en selfs relativistiese benadering tot dissipline (d.i. die vorming van volgelinge) lei tot inkonsekwenthede (die gesagsdraer is wisselvallig in sy of haar beïnvloeding van of leiding aan die gesagsonderhorige), tot 'n laatmaar-vaar-benadering (die gesagsonderhorige word toegelaat om roekeloos die eie kop te volg), onvoorspelbaarheid en wispelturigheid (die gesagsonderhorige is nie altyd seker wat om van die gesagsdraer te verwag nie), en selfs blatante onverantwoordelikheid (die verantwoordelikheid en toerekenbaarheid wat met gesagsuitoefening geassosieer word, word nie nagekom nie, soos onder meer te sien in die optrede van leiers van misdaadbendes).

Ten diepste dui dissipelskap in die onderrig-leersituasie in die skool op volgelingskap: die onderwyser (as opvoeder) behoort die leerder (as opvoedeling) te lei en toe te rus om die Goddelike wetmatighede in die skepping (as God se wil vir die skepping) raak te sien, en ook om die eie lewe gewillig te skik volgens hierdie Goddelike wil (wette en verordeninge) wat ten grondslag van die wetmatighede lê. In die skool, as 'n samelewingsverband gerig op die optimale uitvoering van die onderrig-leersituasie asook op die toerusting van die leerders (as opvoedelinge), moet hierdie gedagte van volgelingskap besondere aandag kry. 'n Dissipel is iemand wat die (skeppingssowel as Skrif-) Woord van God hoor en dit ook doen. Deur nie slegs te hoor nie, maar deur ook die wil van God te doen, is die dissipel 'n dienaar van God. Hierdie diens vertoon twee kante: om vir ander mense en die skepping in die algemeen te sorg en ook om "heel" te maak (vgl. Gal. 5:13-14). Die uiteindelike doel van 'n dissipel is om te lewe ooreenkomstig die bedoelinge en verordeninge van God, in sowel woord as daad. In opvoedingskonteks kom die bemoeienis van die opvoeder met die opvoedeling neer op die voorbereiding en toerusting van laasgenoemde tot diens van God en die naaste. Hierdie dienswerk word in hierdie gebroke bedeling nog aangetas deur die sonde; desondanks beteken dissipelskap om Christus in woord en daad te volg. Om 'n dissipel te wees is om, binne die raamwerk van menslike beperkinge, mee te werk aan die vernuwende en herstellende werk van Jesus Christus. Volkome dissipelskap kom neer op die volledige en toegewyde doen van daardie take waarvoor God die mens op die aarde geplaas het. Dissipelskap só beskou, is die uiteindelike en omvattende doel van alle opvoedingswerk, ook waar dit in die konteks van skoolgebaseerde onderwys plaasvind (vgl. Van Dyk, 1997:20, 33 e.v.). Dissipline in die klaskamer, konkreet gestel, is om die leerders op 
die regte pad te lei en te hou. Dissipline is dus altyd herstellend en korrigerend van aard (en vereis selde dat straf uitgedeel moet word). Dissipline is ook regstellende werk in die konteks van liefde en vergiffenis vir oortredings, en die dra van mekaar se laste. Dit sluit ook in die gee van waarskuwings en die verlening van steun (Van Dyk, 2000:239-240).

\section{Gevolgtrekking}

Prinsipieel beskou, is dit nie aanvaarbaar om óf in 'n postmoderne óf om in ' $n$ postmoderne benadering tot gesag, vryheid, orde en dissipline vasgevang te raak nie, en ook nie om in "ou", tradisionele hiërargiese beskouinge of die hedendaagse egalitêre visie (van byvoorbeeld gesag) vas te val nie. In die onderwysopset moet die opvoeder (onderwyser, fasiliteerder) tussen al hierdie uiterstes deurstuur, en wel aan die hand van 'n duidelike beginselvisie: soms moet daar wel streng en daadkragtig opgetree word, en ander kere moet daar toeskietlikheid, toelating en begrip wees. Hierby kom dat, hoewel gesag en dissipline (dissipelvorming) altyd universeel-vaste kante het, dit in partikuliere en kontingente situasies verbesonder moet word. Daar behoort altyd gereken te word met die besondere aard en omstandighede van die opvoeder en die opvoedeling in ' $n$ besondere situasie. Daar moet in die beginseldenke oor gesag, dissipline, vryheid en orde altyd ewewig wees tussen die objektiewe, algemeen-geldige beskouing (sg. view from nowhere) en die subjektiewe belewing van byvoorbeeld gesagsuitoefening of ordehandhawing (sg. ek-perspektief).

Daar was altyd 'n neiging, toe te skryf aan die sondige aard van menswees (vgl. die lewensbeskoulike vraag: Wat het verkeerd gegaan met die situasie waarin ons ons bevind?), vir gesagsdraers om in prinsipieel onregverdigbare uiterstes te verval. Voorbeelde kan genoem word van outokratiese en totalitêre optrede deur gesagsdraers (vgl. die voorbeelde wat genoem word in die artikel "A classical approach to the restoration of discipline in South African schools" in hierdie bundel). Daar kan eweneens voorbeelde genoem word van losbandige gedrag (vgl. "Drug testing in American schools" in hierdie bundel).

Die verval van dissipline in skole (in Suid-Afrika maar ook in ander lande) het die skrywers van die bydraes in hierdie bundel genoop om andermaal ondersoek in te stel na verskillende aspekte van gesagsuitoefening, vryheidsbelewing, orde-herstel en dissipline in die onderwysopset in Suid-Afrika. Hierdie inleidende besinning tot die bundel het aan die lig gebring dat daar telkens teruggevra moet 
word na die Bybelsgefundeerde (reformatoriese) beginsels wat die verskillende vraagstukke rondom gesaghandhawing en dissipline in skole ten grondslag lê.

\section{Bibliografie}

DE KLERK, W.J., DUVENAGE, B. \& VAN WYK, J.H. 1973. Roeping en werklikheid. Potchefstroom : Herald.

FERNHOUT, H. 1997. Christian schooling: telling a world view story. (In Lambert, I. \& Mitchell, S. The crumbling walls of certainty. Sydney : Centre for the Study of Australian Christianity. p. 75-98.)

FOWLER, S. 1991. A Christian voice among students and scholars. Potchefstroom : IRS.

HARGREAVES, A. 1994. Changing teachers, changing times. Teachers' work and culture in the postmodern age. London : Cassell.

HUMALDA, D. 1995. De waardendiscussie als (op)gave. (In Miedema, S. \& Vijver, H.W., reds. Visie als venster. Kampen : Kok. p. 60-74.)

MIDDLETON, J.R. \& WALSH, B.J. 1995. Truth is stranger than it used to be. Downers Grove : InterVarsity Press.

MOORE, S.H. 1996. Era and epoch, epoch and era: Christian intellectuals in the postmodern turn. Christian Scholar's Review. Special issue on Christianity and Postmodernity, XXVII:133-137.

NEUTJENS, C. 2000. Het Christendom in een postmodern perspectief. Koers, 65(3):281-340.

O'LOUGHLIN, M. 1999. New research epistemologies in a changing social landscape. Education as Change, 3(1):48-58.

PADGETT, A.G. 1996. Christianity and postmodernity. Christian Scholar's Review. Special issue on Christianity and Postmodernity, XXVII:129-132.

REPUBLIEK VAN SUID-AFRIKA. 1996. Grondwet van die Republiek van SuidAfrika. Wet no. 108 van 1996.

STEYN, S.C., WOLHUTER, C.C., OOSTHUIZEN, I.J. \& VAN DER WALT, J.L. 2003. An international perspective on learner discipline in schools. South African Journal of Education, 23(3):225-232.

STONE, H.J.S. 1981. Die aard en struktuur van die skool. Educantulusreeks no. 1. Pretoria : Academica.

TALJAARD, J.A.L. 1976. Polished Lenses. Potchefstroom : Pro Rege.

TENNEKES, J. 1992. Christenen en cultuurvorming. (In De Knijff, H.W., Dekker, G. \& Tennekes, J. Christelijke waarden in een geseculariseerde cultuur. Amsterdam : VU Uitgeverij. p. 35-62.)

VAN DER WALT, B.J. 1999. Visie op die werklikheid. Potchefstroom : IRS.

VAN DER WALT, B.J. 2003. Om 'n leier te wees - vanuit 'n Christelike perspektief. Koers 68(2 \& 3):143-170).

VAN DER WALT, J.L. 2002. Knowledge and science in a changing intellectual climate. Potchefstroom : Centre for Faith and Scholarship.

VAN DER WALT, J.L. \& DEKKER, E.I. 1983. Fundamentele opvoedkunde vir onderwysstudente. Potchefstroom : Media Publikasies.

VAN DYK, J. 1997. Letters to Lisa. Conversations with a Christian teacher. Sioux Center : Dordt.

VAN DYK, J. 2000. The Craft of Christian Teaching. A classroom journey. Sioux Center : Dordt. 
WARD, G. 1997. (Teach yourself) Postmodernism. Lincolnwood : Hodder \& Stoughton.

\section{Kernbegrippe:}

gesag, vryheid, orde en dissipline in die onderwys

postmoderne benadering tot gesag, vryheid, orde en dissipline in die onderwys

Bybels-prinsipiële benadering tot gesag, vryheid, orde en dissipline in die onderwys

\section{Key concepts:}

authority, freedom, order and discipline in education

post-modern approach to authority, freedom, order and discipline in education

Biblical-principial approach to authority, freedom, order and discipline in education 